University of Vermont

UVM ScholarWorks

$1-1-2011$

\title{
Incorporating systems thinking and sustainability within civil and environmental engineering curricula at UVM
}

\author{
Nancy J. Hayden \\ University of Vermont \\ Donna M. Rizzo \\ University of Vermont \\ Mandar M. Dewoolkar \\ University of Vermont \\ Lalita Oka \\ University of Vermont \\ Maureen Neumann \\ University of Vermont
}

Follow this and additional works at: https://scholarworks.uvm.edu/cemsfac

Part of the Climate Commons, Community Health Commons, Human Ecology Commons, Nature and Society Relations Commons, Place and Environment Commons, and the Sustainability Commons

\section{Recommended Citation}

Rizzo, D. M. (2011, June), Incorporating Systems Thinking and Sustainability within Civil and Environmental Engineering Curricula at UVM Paper presented at 2011 ASEE Annual Conference \& Exposition, Vancouver, BC. 10.18260/1-2--18134

This Conference Proceeding is brought to you for free and open access by the College of Engineering and Mathematical Sciences at UVM ScholarWorks. It has been accepted for inclusion in College of Engineering and Mathematical Sciences Faculty Publications by an authorized administrator of UVM ScholarWorks. For more information, please contact scholarworks@uvm.edu. 
AC 2011-2918: INCORPORATING SYSTEMS THINKING AND SUSTAINABILITY WITHIN CIVIL AND ENVIRONMENTAL ENGINEERING CURRICULA AT UVM

Dr. Donna M. Rizzo, University of Vermont 


\title{
Incorporating Systems Thinking and Sustainability within Civil and Environmental Engineering Curricula at UVM
}

\author{
Nancy J. Hayden, Donna M. Rizzo, Mandar M. Dewoolkar, Lalita Oka and Maureen Neumann \\ University of Vermont
}

\begin{abstract}
As part of an NSF Department Level Reform (DLR) grant, the civil and environmental engineering programs at the University of Vermont (UVM) incorporated systems thinking and a systems approach to engineering problem solving within their programs. A systems thinking approach regards social, environmental and economic factors as necessary components of the problem solution. Because it is a whole systems approach it also encompasses sustainability. We have integrated systems thinking in the following ways; 1 ) new material has been included into key courses (e.g. the first-year introductory and senior design courses), 2) a sequence of three related environmental and transportation systems courses have been included within the curricula (i.e., Introduction to Systems, Decision Making, and Modeling), and 3) service-learning (S-L) projects have been integrated into key required courses as a way of practicing a systems approach. This culminates in the senior design course in which many of the projects specifically focus on sustainability. A variety of assessment methods have been implemented as part of our reform including student surveys, focus groups, faculty interviews, and assessment of student work. We specifically designed a survey tool that addressed sustainability understanding (both open ended and Likert scale). The survey was given to first-year first semester (FYFS) civil and environmental engineering students, FYFS environmental science students, and senior civil and environmental engineering students. Approximately $50 \%$ of the incoming civil and environmental engineering students could not define or give reasonable examples of what sustainability means, while their counterparts in environmental science showed that almost $100 \%$ could provide a good definition and provide reasonable examples of sustainability. However, by the end of the introductory course in engineering, the majority of the engineering students had a good working definition of sustainability and examples. Female students in both groups showed a statistically significantly higher interest in learning about sustainability than their male counterparts.
\end{abstract}

\section{DLR Reform}

The goal of our NSF-sponsored Department Level Reform (DLR) grant was to incorporate a systems approach to engineering problem solving within the civil and environmental engineering programs. The reform was motivated by numerous reports and papers written in the past ten or so years on the needs for the engineering education for the $21^{\text {st }}$ century (e.g. NAE 2004, 2005; NSB 2007; Duderstadt 2008; ASCE 2006, 2008), which promote inclusion of sustainable practices, a systems approach and inquiry-based learning in engineering curricula among other things. A systems approach challenges engineers to incorporate environmental, social, and economic considerations, as well as technical aspects within engineering solutions. Likewise, definitions of sustainability often suggest a more holistic approach to problem solving that includes the triple bottom line (i.e., economic viability, and social and ecological justice). Ashford (2004) discussed major challenges to engineering education in relation to sustainable 
development. With this overarching theme, our reform has taken a multi-pronged approach in two main areas that include implementing: a) a sequence of three systems courses related to environmental and transportation systems that introduce systems thinking, sustainability, systems analysis and modeling; and b) service-learning (SL) projects as a means of practicing the systems approach. Details of this reform can be found in Dewoolkar et al., (2009a, b, and one in revision), Hayden et al., (in revision), Lathem et al., (in revision) as well as our website: www.uvm.edu/ sysedcee.

The creation of three interconnected systems courses was critical for our reform. These courses incorporate fundamentals of engineering economics, environmental engineering and transportation engineering within a systems thinking framework. The first introductory systems course introduces systems thinking, growth, feedback loops, limits to growth, basic engineering economics and environmental engineering. The second systems course in decision making builds on the first, while introducing transportation engineering systems, and environmental and social impacts of transportation systems. The third course builds on fundamentals and attempts to tie various issues together from a systems modeling approach (Hayden et al., in revision).

Systems modeling helps create awareness that systems exist (and can be identified) in the interactions among people, economic forces and environmental responses. As a result, it unifies subjects that existed independently in our engineering curricula. In the third systems course, modeling skills and the use of behavior-over-time graphs, stock/flow diagrams, and causal loops to assist in developing a causal viewpoint and sustainable outlook to engineering applications are developed. The act of trying to model a system forces recognition that the system's structure generates its behavior; and it allows students to observe patterns and trends (via graphical interface) as the system changes over time (iseesystems 2004). The hope is that improved understanding of these system patterns (and often the unintended emergent consequences) will help students consider engineering design-related issues more fully, and resist the urge to come to a quick conclusion thus develop long-term sustainable thinking.

Our SL projects are good examples of inquiry-based learning that allow students to emphasize research and learning in areas of most interest to them (i.e., inquiry-based). The SL projects address real-world open-ended problems and emphasize academic and intellectual development, civic engagement, and personal/interpersonal skills for the student while providing a meaningful service to the community partner. Examples of sustainability in the SL projects within required courses at different levels are given below.

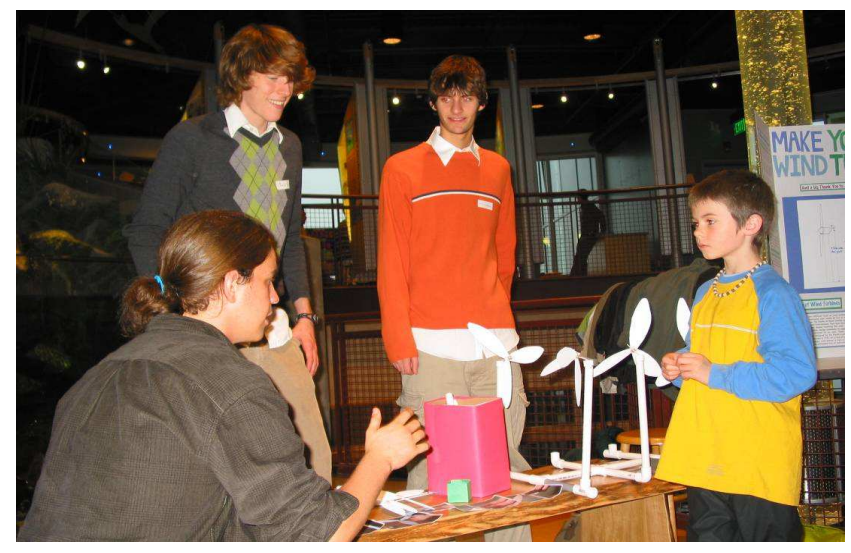

Science Center Prototype Exhibits and Presentations: First-year students conducted research, designed and built exhibit prototypes and presented their projects in a public forum for ECHO (Lake Champlain Science Museum) that focused on engineering and sustainability issues related to the Lake. 
Stormwater Bioretention Facility: Sophomore students learned about low impact design, develop IT skills, and considered economics in decision making as related to the possible introduction of a "raingarden" near one of UVM's parking lots.

Mentoring Children using Biomimicry Projects: Teams of juniors worked with local homeschooled (K-12) children to create innovative solutions to problems of mobility, while using the fun and inspiration of biomimicry.

Low Impact Design using Green Roofs and Porous Pavement: Seniors worked in teams to design solutions to stormwater runoff for Burlington (with a combined (sanitary + stormwater) sewer system) in the senior capstone design course. They analyzed stormwater runoff in parts of Burlington to determine impact on wastewater treatment plant capacity, performed structural analysis of building to determine feasibility of adding the additional weight of a green roof, and the impact of including porous pavement in the city.

\section{Sustainability Survey}

We designed a survey tool that asked students questions related to sustainability understanding (both open ended and using a Likert scale). The survey was given to first-year first semester (FYFS) civil and environmental engineering students in the introductory civil and environmental engineering class, FYFS environmental science students in their introductory course, civil and environmental engineering students (in the senior capstone design class), and an upper level/graduate elective course in sustainable water and waste systems.

Open ended questions included; 1) define sustainability, 2) describe sustainable practices, and 3) give examples of your sustainable practices. These were evaluated in the following manner. Students who could not define sustainability nor provide examples that were meaningful were given a 0 (no understanding). Students who could not define sustainability but could define some types of sustainable practices were awarded a 1 (some understanding). Student who could provide a reasonable definition related to environmental impact or resource impact and meaningful examples were awarded a 2 (environmental understanding), students who could provide a reasonable definition that included one of the other key factors used in the triple bottom line approach (e.g. social impact or economic viability) were awarded a $3 \mathrm{~s}$ (social) and $3 \mathrm{e}$ (economic). If they gave a triple bottom line type answer they were awarded a 4 . If students could articulate either through examples or in the definition a more holistic belief (true believers which was subjective) they were awarded a + . Sustainability "experts" from the UVM Office of Sustainability are evaluating these responses without knowledge of the group they were evaluating to verify our own analysis.

Figure 1 shows the results of FYFS students in engineering (pre and post the introductory class which covered sustainability topics), FYFS students in environmental science, senior civil and environemntal engineering students and the graduate class. Student responses of 2 and higher were combined for ease of viewing, although almost all first-year (pre) and senior engineering students could only articulate environmental understanding. It was not surprising that the seniors and graduate students in the sustainable water and waste systems course had the greatest overall understanding of sustainability as well as being the most committed to sustainable practices. For 
example, 21 out of 24 students in the elective course received the "+" rating (88\%), as compared to $3 \%$ for the senior engineering course, and $4 \%$ for the FYFS environmental science students.

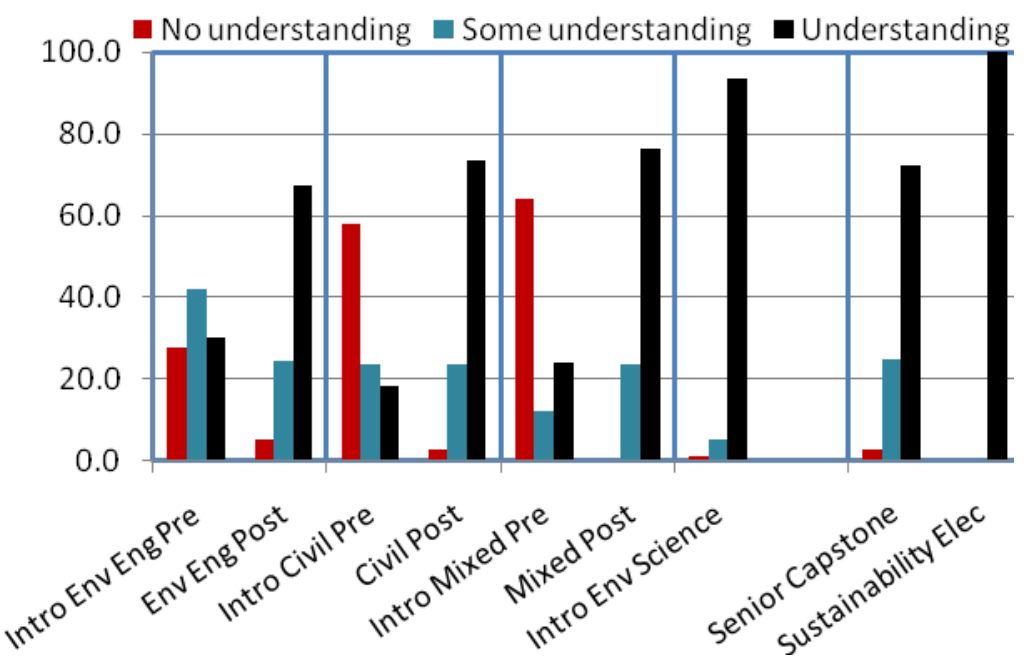

Figure 1. Results of openended responses dealing with student understanding of sustainability.

Overall, the environmental science students showed a greater understanding of sustainability than their engineering counterparts even as compared to the results (post) at the end of the civil and environmental introductory course. FYFS environmental science students also showed a statistically significant difference (Pearson's test 0.0259>chi sq) when compared to senior engineering students.

It is also interesting to note that the senior civil and environmental engineering students did not have a better grasp of the term sustainability than their freshman counterparts (post results) at the end of the freshman course as suggested by the survey responses. However, the survey questions related to defining sustainability may not necessarily measure the depth of understanding. This semester we are including additional assessment of our seniors by evaluating their reflection papers and report writing in the senior capstone class. This may provide more insight into their understanding of these important concepts.

However, it may be that these engineering students are not as interested in these issues as other aspects of engineering. For example, when students were asked to rate how important learning about sustainability was to them in their college education (very important, important, neutral, unimportant, and very unimportant), only $44 \%$ of the senior engineering students rated that as 'very important,' although over $97 \%$ of them rated it as either 'important' or 'very important.' For FYFS students, the ratings of learning about sustainability as 'very important' in their college education were much higher. For example; $75 \%$ of environmental science students, $69 \%$ of environmental engineering students, $61 \%$ of civil engineering students, and $56 \%$ of undecided engineering students rated sustainability as 'very important.' These findings support the conclusions of Azapagic et al. (2005) who noted that while students think sustainability is important there are significant knowledge gaps in their understanding.

Some of these differences may be attributed to the number of female students in the various programs since there were many more female students in environmental science (49.23\%) than 
in engineering (21.11\%). There was a significant statistical difference (Pearson's test $0.0020>$ ChiSq) between male and female students in their interest in learning about sustainability, but no difference between female students in either science or engineering. The majority of female students $(82 \%)$ in both science and engineering FYFS class rated learning about sustainability as 'very important.'

\section{Concluding Remarks}

This paper presents initial assessment findings on differences in understanding sustainability between civil and environmental engineering students (FYFS and seniors after going through the curriculum reform) and FYFS environmental science students. Approximately $50 \%$ of the incoming civil and environmental engineering students in our program had limited knowledge of what sustainability was even though they thought it was important to learn about it. Their counterparts in environmental science showed that almost $100 \%$ could provide a good definition and provide reasonable examples of sustainability. By the end of the introductory course in engineering, the majority of the engineering students had a good working definition of sustainability and examples. Female students in both groups showed a statistically significantly higher interest in learning about sustainability than their male counterparts.

\section{Bibliography}

ASCE (2006), The Vision for Civil Engineering in 2025, prepared by the ASCE Steering Committee to Plan a Summit on the Future of the Civil Engineering Profession in 2025.

ASCE (2008), Civil Engineering Body of Knowledge for the 21st Century Preparing the Civil Engineer for the Future, prepared by the Body of Knowledge Committee of the Committee on Academic Prerequisites for Professional Practice, American Society of Civil Engineers, Second Edition. From http://www.asce.org/professional/educ/bok2.cfm

Ashford, N. A. (2004), "Major challenges to engineering education for sustainable development: what has to change to make it creative, effective, and acceptable to the established disciplines", International Journal for Sustainability in Higher Education, 5(3), 239-250.

Azapagic, A., Perdan, S., and Shallcross, D. (2005), "How much do engineering students know about sustainable development? The findings of an international survey and possible implications for the engineering curriculum", European Journal of Engineering Education, 30(1), 1-19.

Dewoolkar, M. M., George, L. A., Hayden, N. J., and Neumann, M. (2009a), "Hands-on undergraduate geotechnical engineering modules in the context of effective learning pedagogies, ABET outcomes, and curricular reform", J. of Professional Issues in Engineering Education and Practice, 135(4), 161-175.

Dewoolkar, M. M., George, L. A., Hayden, N. J., and Rizzo, D. M. (2009b), "Vertical integration of service-learning into civil and environmental engineering curricula", International Journal of Engineering Education, 25(6), 1257-1269. 
Dewoolkar, M. M., Porter, D., and Hayden, N. J., "Service-learning in engineering education and heritage preservation," in revision, International Journal of Architectural Heritage Conservation, Analysis and Restoration.

Duderstadt, J. J. (2008) Engineering for a Changing World, A Roadmap to the Future of Engineering Practice, Research, and Education, The Millenium Project, The University of Michigan.

Hayden, N. J., Rizzo, D. M., Dewoolkar, M. M., Neumann, M. D., Lathem, S., and Sadek, A., "Incorporating a systems approach into civil and environmental engineering curricula: the effect on student work, and student and faculty attitudes," accepted, in revision, Advances in Engineering Education.

iseesystems (2004), An Introduction to Systems Thinking: ithink Software, ISBN 0-9704921-03.

Lathem, S., M. Neumann, N. Hayden. "The Socially Responsible Engineer: Assessing Student Attitudes of Roles and Responsibilities," accepted with revision, Journal of Engineering Education.

NAE (2004), The Engineer of 2020: Visions of Engineering in the New Century, National Academy of Engineering, Clough, G. Wayne (chair), Washington DC: National Press.

NAE (2005), Educating the Engineer of 2020: Adapting Engineering Education to the New Century, National Academy of Engineering, Clough, G. Wayne (chair), Washington, DC: National Press.

NSB (2007), Moving Forward to Improve Engineering Education, ad hoc Task Group on Engineering Education, Committee on Education and Human Resources, NSB-07-122, November 19, 2007, National Science Foundation. 